\title{
Does Corporate Social Responsibility Need Social Capital?
}

\author{
Stefanie B. Hiß \\ Max Planck Institute for the Study of Societies, Germany
}

\begin{abstract}
MPIfG Journal Article
Stefanie B. Hiß: Does Corporate Social Responsibility Need Social Capital? In: Journal of Corporate Citizenship (23), 81 - 91

(2006). Greenleaf Publishing

The MPIfG Journal Articles series features articles by MPIfG researchers and visiting scholars published in peer-reviewed journals. Max Planck Institute for the Study of Societies (MPIfG) Cologne | www.mpifg.de
\end{abstract}

This paper raises the question of whether controlling corporations through a monitoring system is a successful way to establish social standards within the supply chain. Since the debate thus far has concentrated strongly on the question of what monitoring systems look like and how they are implemented, this paper broadens the discussion by pointing out possible interrelations between the role of social capital and the diffusion of social standards. Therefore, an alternative concept of social capital is developed. It is shown that the right 'composition' of social capital is a necessary 'ingredient' for spreading social standards in the supply chain and into developing countries. These considerations are illustrated with a practical example of a public-private partnership project in the German retail sector.

Codes of
conduct
Corporate social
responsibility
Monitoring
Multinational
corporations
Public-private
partnership
Social capital
Social standards

Dr Stefanie B. Hiß is a researcher at the Max Planck Institute for the Study of Societies in Cologne, Germany. In 2005, she completed her PhD in sociology with the thesis: 'Corporate Social Responsibility: A Myth? Scope and Limits of the New Institutionalism in Sociology'. She has masters' degrees in political science and economics.

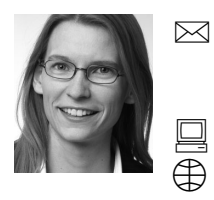

Max Planck Institute for the Study of Societies, Paulstraße 3, 50676 Köln, Germany hiss@mpifg.de www.mpifg.de/people/hs 

process of the diffusion of social standards. This question arises in the following context. When confronted with the societal demand to act in accordance with corporate social responsibility (CSR), multinational corporations (MNCs) more and more often react by establishing voluntary codes of conduct for social standards ${ }^{1}$ throughout their supply chain. Originally, at the beginning of this process, corporations often declined any responsibility for their supply chain (e.g. Locke 2003: 5I). They established codes of conduct that were limited to the realms of their corporation and received no credible monitoring. In reaction to an intense public debate, an increase of critical campaigns and customers boycotts, more corporations now see themselves challenged not only to establish a code of conduct but also to establish a more credible external, independent system of monitoring for both their corporation and their whole supply chain, reaching far into developing countries. Several monitoring systems have been developed that try to optimise control and raise social standards within the supply chain.

This paper raises the question of whether controlling corporations through improved monitoring systems alone can be a successful way of establishing social standards within the supply chain and of helping to spread social standards in developing societies. Even if it were possible with the help of a monitoring system to establish compliance with a certain code of conduct, it is unclear whether the values associated with it would be accepted by developing societies and could therefore be implemented in a sustainable way. As the debate has concentrated strongly on the question of what monitoring systems look like and how they are implemented, I want to broaden the discussion by pointing out the possible interrelations between the role of social capital and the diffusion of social standards. In the prevailing debate this interconnection of social standards and social capital is widely neglected. It will be shown that the right 'composition' of social capital is a necessary 'ingredient' for spreading social standards throughout the supply chain and into developing countries.

The remainder of the paper is set out as follows. First of all, I will give a short introduction to the scope and limits of monitoring systems. As even elaborate monitoring may not be enough to spread social standards throughout the supply chain, I introduce the concept of social capital as a potential supplement to monitoring systems. In this way an alternative concept of social capital is developed. This will allow the ways in which social capital and the diffusion of social standards are interrelated to become clear. These considerations are illustrated with a practical example of the public-private partnership project 'Sector Model Social Responsibility' of the Foreign Trade Association of the German Retail Trade (Außenhandelsvereinigung des Deutschen Einzelhandels [AVE]) in cooperation with the German development agency (Deutsche Gesellschaft für Technische Zusammenarbeit [GTZ]).

1 The following distinction concerning social standards is usually made. On the one hand, the broad term 'social standards' is used more generally in the literature as a comprehensive term for minimum standards with respect to the provision of labour contracts (e.g. working time, wages, social insurance, etc.) and labour rights. On the other hand, the more specific term 'core labour standards' refers to the definition of the International Labour Organisation (ILO) (Windfuhr 2004: IO5). In its 'Declaration on Fundamental Principles and Rights at Work' the ILO identified initially seven, now eight, key conventions as 'core labour standards'. The Declaration covers four areas: freedom of association and the right to collective bargaining; the elimination of forced and compulsory labour; the abolition of child labour; and the elimination of discrimination in the workplace (ILO n.d.). 


\section{The monitoring process of codes of conduct on social standards}

The development of monitoring systems ${ }^{2}$ can be seen as a reaction to the criticism that codes of conduct have been implemented in an unreliable way. There is a wide spectrum of different monitoring systems, ranging from internal to independent or external monitoring systems. Definitions of the terms within this spectrum also vary considerably. ${ }^{3}$ Usually, 'internal' monitoring is defined as a form of monitoring conducted by the corporation itself. By this means the corporation integrates the monitoring into its normal quality management, which puts it on a more regular footing but keeps it in the corporation's area of responsibility. External or independent monitoring is more credible and is conducted by an independent organisation: for example, a nongovernmental organisation (NGO) (Fuchs 2000: 297ff.; IG Metall Vorstand et al. 200I: 62; Urminsky 200I: 32; Ascoly and Zeldenrust 2003: 8ff.).

Theoretically, these different monitoring systems can be seen as complementary. While internal monitoring, especially in the form of an integrated management system, can help to spread social standards throughout a company culture, independent or external monitoring can exert 'real' control in a more legitimate manner (ILO I998: No. 66). However, there are various cases where it is difficult to find out how the monitoring systems work and whether or not they are credible. Therefore, there is an intense debate about how to improve the credibility and effectiveness of monitoring systems. Criticism often takes the following forms.

First, systems of monitoring codes of conduct are often limited to spot-check controls that are not very frequent. In many cases, during a one- or two-hour visit, monitors interview the management about employment issues and are guided around the premises. They are therefore only able to identify 'obvious' violations of the code of conduct. ${ }^{4}$ As a result, no real and continuous pressure for a sustainable and effective improvement of social standards can be exerted. Additionally, monitoring systems are limited with respect to their area or sphere of influence. Any possible control cannot reach the informal sector (e.g. so-called sweatshops) or the far ends of the supply chain of the formal sector, at least when it is organised as a complicated system of sub-subcontractors or in the form of long, shifting subcontracting chains (Murray I998: 32ff.; Röben I999: 8; Reichert 2004: 8). In the worst case, a code of conduct may result in a relocation of work from the formal to the informal sector (Reichert 2004: 7 ff.).

A second criticism concerning monitoring focuses on the dependency structures. Suppliers often only comply with the relevant code of conduct because, financially, they are strongly dependent on their buyers: for example, the large retailers, merchandisers, brand-name corporations or their intermediaries. For them, compliance with the codes of conduct above the minimum required by the monitoring standards does not make sense since it can involve economic disadvantages. For example, the time limits for fulfilling a contract in the textile industry are sometimes only a few days or weeks. The supplier finds itself faced with the dilemma of either producing the goods on time or risking the loss of its buyer. This kind of pressure is passed on directly to the workers, resulting in, for example, enforced overtime. Additionally, adherence to codes of conduct sometimes has the effect of making workers perceive them as unfavourable. An exam-

2 Empirically, the OECD (Organisation for Economic Co-operation and Development) lists 246 codes of conduct, but only I37 include internal monitoring and only 26 permit independent or external monitoring (Wick 2003: 23).

3 Alternatively, there is the distinction between first-, second- and third-party monitoring. Usually businesses see themselves as the first party, the suppliers as the second party and the monitor as the third party (Ascoly and Zeldenrust 2003).

4 Women Working Worldwide, www.women-ww.org/codes_pack7.htm. 
ple is the workers' rejection of the prohibition of overtime. As such, this prohibition is designed to protect workers, but as overtime working hours are necessary for them to earn the minimum wage they need for their survival, they tend to reject the social standard. As a result, social standards as framed in a code of conduct are very often perceived as a 'strange', 'isolated' and 'disconnected' element. In these circumstances, intensifying control seems a rather limited approach to diffusing social standards. Instead, there is a need for reciprocal understanding and for an exchange of views on the different cultural interpretations of social standards and their value for society as a whole. In this sense, monitoring systems are not enough. Due to structures of economic dependency and different cultural interpretations of social standards, monitoring systems have to be supplemented by something else. Only then can the obstacles to a better diffusion of social standards be overcome.

Below I argue that social capital is the missing link between monitoring systems and the diffusion of social standards. Social capital can be seen as a translator or 'transmitter' that transforms formal codes of conduct into interculturally accepted social standards.

\section{Social capital}

Before focusing on the interconnections between social standards and social capital, we have to take a closer, critical look at the highly ambiguous and controversial concept(s) of social capital. In the broad debate about social capital, not only are there questions raised about its conceptualisation and measurement, but the concept is also criticised for giving rise to 'vague ideas' and 'casual empiricism' (Solow 2000). ${ }^{5}$

One of the shortest definitions of social capital has been formulated by Woolcock (200I: I2): 'It's not what you know, it's who you know'. Further he describes: 'the basic idea of social capital is that one's family, friends and associates constitute an important asset, one that can be called upon in a crisis, enjoyed for its own sake, and/or leveraged for material gain'. He-like many others - sees social capital as a resource in the form of one's membership within a network and a set of shared norms and values. If drawn on, this resource facilitates collective action. Other possible components of social capital are seen in the role of trust and trustworthiness (e.g. Gambetta I988; Fukuyama I995; Ostrom and Ahn 2003), in the aspect of civil-society engagement (e.g. Putnam I993, I995, 2000) or in the way that institutions can be understood to be social capital (e.g. Ostrom and Ahn 2003). Outside academic circles the term 'social capital' is increasingly used for policy purposes (Dolfsma and Dannreuther 2003: 405ff.). The World Bank, for example, sees social capital as a key element in combating poverty and inequality. It uses the following definition:

Social capital refers to the institutions, relationships, and norms that shape the quality and quantity of a society's social interactions ... Social capital is not just the sum of the institutions which underpin a society—it is the glue that holds them together (World Bank 1999).

Bourdieu, Putnam and Coleman are the authors most often credited with introducing key thoughts and impulses to the contemporary debate about social capital. As part of his concept of different kinds of capital, Bourdieu (1983) sees social capital as a resource used by privileged people to maintain their upper status within society. Coleman (I988, I990) has a more optimistic view. He defines social capital as a public good which almost

5 For detailed introductions to the concept of social capital, please see Dasgupta and Serageldin 2000; Baron et al. 2000; Lin 200I; Lin et al. 200I; Ostrom and Ahn 2003; Field 2003. 
entirely brings about benign results: on the basis of clear norms and sanctions, individuals co-operate for mutual advantage. Putnam (1993, I995, 2000), who differentiates between bonding and bridging social capital, also has a rather optimistic view, seeing functioning networks as the precondition for a viable civil engagement leading to healthy civil societies.

All three understand social capital, in the form of networks and shared norms and values, as resources for co-operation and mutual advantage. Actors capable of drawing on these resources improve their personal well-being and their status within society. While Bourdieu describes social capital as an exclusive asset of the privileged groups of society, Coleman and Putnam optimistically assume that social capital may be employed by almost everybody for everyone's sake. Implicitly, the vision is formulated of the resources and capabilities that constitute social capital being employed for favourable ends. Unfortunately, as a few authors point out (e.g. Woolcock I998; Fukuyama 2000; Ostrom and Ahn 2003; Field 2003), this is not always the case.

When social capital is 'used' by a select group to make large profits at the expense of individuals that are not part of this group, social capital is said to have a dark side. Ostrom and Ahn (2003: xiv) give several examples:

This dark side of social capital can involve police gaining trust in each other to collude not to report excessive force ... corporations or nations colluding with one another to create cartels ... or members of the Mafia colluding to undertake illegal economic activities.

Thus, social capital is not something inherently good, even if co-operation on the basis of networks and shared norms and values may lead to favourable outcomes. When employed for exclusive objectives, social capital may fall victim to misuse. A great number of social capital concepts implicitly contain a normative content (often of an optimistic nature).

It is the aim of this paper to remedy this situation by introducing an alternative concept that makes this normative content explicit. While the aforementioned definitions describe 'positive' qualities of social capital, there is no explicit mentioning of a 'normative' quality of social capital. In the following systematisation, 'social capital' will be analytically differentiated according to its 'positive' and 'normative' qualities. More precisely, the following qualities will be distinguished:

Social capital as a resource ('positive')

- Social capital as a capability ('positive')

- Social capital as 'capital to be social' ('normative')

\section{Social capital as a resource}

The qualities related to 'social capital as a resource' are seen mainly in the structural component of the concept: for instance, in structures of networks, shared norms and values, established trust or reputation. A possible example of 'social capital as a resource' is membership of a network such as a multi-stakeholder forum. Such affiliations can be seen as a valuable resource to an MNC for obtaining information about stakeholders' views on CSR in order to access the contemporary debate in a manageable, personal and perhaps trustful circle.

This, however, should be distinguished from the different ways in which to use such resources. In my view, this depends essentially on the capability: for example, the ability to develop alliances through trustworthy behaviour or to build up a good reputation with the help of networks. 
In addition to 'social capital as a resource', the qualities related to 'social capital as a capability' are seen mainly in the process component of the concept. We can regard this as the capacity to develop, use, activate or obtain resources such as networks, contacts and trust. For example, a person or a corporation with a high level of social capital can more easily create alliances and facilitate co-operation, better communicate and diffuse its own values and norms, or manipulate the public with the help of public relations.

'Social capital as a resource' and 'social capital as a capability' are closely connected with each other, and therefore the distinction has often more the character of an analytical one. Both are unthinkable without social interaction. Building up a resource requires the capability to do so, and vice versa. As with Giddens's structuration theory, resources and capabilities are interrelated. Actors need resources to elaborate their capabilities and, in the process of doing so, reproduce the resources.

The two qualities of social capital discussed so far are applicable to a wide range of objectives but operate irrespective of any goal such as public welfare. They can therefore be described as 'positive' rather than 'normative' qualities. In order to determine the normative aspect of social capital, let us invoke a third quality.

\section{Social capital as 'capital to be social'}

The Italian Mafia, widely perceived as a force contradicting public welfare, can be described, following the qualities of social capital mentioned above, as having a high level of social capital. In many parts of southern Italy the Mafia has close networks, commonly shared values and enjoys a certain trustworthiness on the part of its members. From the differentiations outlined thus far, this could be described as a high level of 'social capital as a resource' and 'social capital as a capability'. On the other hand, a society attributed with a high level of social capital would not normally be associated with the Mafia. Instead, a high degree of civil engagement, general trust and shared norms and values are generally interpreted as social capital, correlated with a positive attitude towards public interest and public welfare. Therefore, I will introduce the third quality of 'capital to be social'. Here, 'social capital as a resource' and 'social capital as a capability' are oriented towards and may be used to further public welfare. The ideas and realisations of what is best for 'public welfare' can vary immensely. Nevertheless, by taking social standards into account, the International Labour Organisation (ILO)'s core labour standards become the main framework of reference. But how exactly these conventions and norms are interpreted and realised has to be discussed in relation to the respective societal context.

While the first two 'positive' qualities of social capital are potentially neutral in a normative way, social capital as 'capital to be social' introduces an explicitly teleological component into the social capital concept. In this way, it tries to operationalise the aforementioned and rather abstract definition of the World Bank, that 'social capital is the glue that holds society together' (World Bank i999).

Below, I use the distinctions I have drawn between the qualities of social capital to discuss the possible impact of social capital on the diffusion of social standards.

\section{Social capital and the diffusion of social standards}

The debate about the voluntary social standards of MNCs is highly focused on the monitoring systems for codes of conduct. Therefore, the main focus is on the intraorgani- 
sational working conditions of MNCs and their supply chains. Given this narrow perspective on the diffusion of social standards through monitoring, the wider societal preconditions that are necessary for a sustainable implementation and for a spillover of social standards into developing societies are overlooked. How can we supplement this narrow perspective with reference to the concept of social capital as developed above?

The diffusion of social standards has to overcome different cultural borders because the supply chains of MNCs often extend far into other societies. For example, MNCs in the textile sector are mostly 'at home' in rather developed industrialised nations, but mainly produce in developing countries where they are confronted with a different cultural background and more unfavourable working conditions, especially for unskilled workers. In all probability, the implementation of codes of conduct 'from above' means that, throughout the supply chain, they remain somewhat unconnected to the specific cultural background of the people and their perceptions of social standards. Ideally, the implementation of social standards would mean bringing them 'alive' and making them part of the 'scripts', rules and institutions of working life in general. Perhaps social capital can be seen as the essential supplement to bring these social standards 'alive' or, at least, as the missing link.

For a clearer discussion of how to achieve this, it will be helpful first of all to identify the important actors in the supply chain and see what kind of social capital they have or use.

In a rather textbook supply chain, four main actors can be discerned: (a) the heads of the MNCs with their managers, located in a developed country; (b) the workers of the MNCs in the developed country; (c) the supply chain corporations and their managers in the developing countries; and (d) their workers in the developing countries. In the interest of clarity, this rough differentiation excludes other important actors such as NGOs and consumers.

Comparing the situation between the developed and the developing countries we can assume that managers in both countries have social capital as both a resource and a capability. Mostly they will be integrated in networks, they can activate support through alliances, they share values, and so on. However, as they are living in separate 'worlds', this does not mean that they automatically share the same social capital. Further, it could be that large corporations in developed countries have more social capital available as a resource and as a capability compared with suppliers in the developing countries. But what about the third form of social capital: 'capital to be social'?

Suppliers in developing countries, who often find themselves in a highly dependent situation, will probably prefer to utilise their social capital as a resource and capability for their own economical survival, and not necessarily for the implementation of social standards. This is especially the case when social standards are in conflict with economic goals. Similarly, highly shareholder-value-oriented brand-name corporations based in developed countries are dependent on economic success. In the same way, they are dependent on a good reputation among their customers. Obviously, they will try to utilise their social capital as a resource and capability in order to gain such a favourable reputation. For them, social standards or a code of conduct are possible means of reaching this goal, regardless of what they see as being good for public welfare. Of course, there are some traditional, often family-led corporations that support social standards through their ethical conviction. However, this does not necessarily apply to shareholder-valueoriented MNCs.

In the same way, this is related to the question of how much 'capital to be social' is to be found in society. When a society demands the implementation of social standards, as when they are articulated by NGOs, then their campaigns and consumer boycotts are a real threat to the reputation and economic performance of corporations who do not comply with these standards. For them, the incentive to implement social standards 
grows. In this way, 'capital to be social' when it is embedded in society can support the implementation of social standards, but need not necessarily be part of a corporation's motivation in the first place. Nevertheless, with respect to the implementation of social standards, the level of 'capital to be social' in developed countries seems to be higher compared with developing countries.

Moreover, it can be assumed that workers in developed countries have more social capital compared with those in developing countries. In recent decades, workers' minimum rights, such as the core labour standards of the ILO, have become commonplace in developed countries, and their violation has resulted in public protest. Therefore, workers and other people in developed countries not only have a solid basis of 'capital to be social' in their societal environment, but they also have a stable framework of social capital as a resource (e.g. unions) and social capital as a capability (e.g. protests over workers' rights, which are part of the rules and 'scripts' of society). This situation differs fundamentally from that in developing countries. As regards working conditions in these countries (not people's private life), there is no profound societal atmosphere to strengthen or enforce 'capital to be social'; there is just a low level of social capital as a resource (e.g. in the form of unions) and a low level of social capital as a capability (e.g. not trustful, yet highly competitive relations with other workers).

Such considerations have given rise to the thesis that the gap between the managers' social capital and the workers' social capital is much wider in developing countries than in developed countries.

What does this mean with regard to the limits of implementing social standards in a sustainable way through codes of conduct and monitoring systems?

The social standards integrated into a code of conduct convey certain values and norms. The monitoring systems used to control the implementation of social standards have their limits because the 'idea' of social standards and the values and norms incorporated in them do not trickle down into the developing societies. Instead, they remain as isolated entities, unable to take root and spread into a wider societal area.

My argument here is that social standards can be implemented in a more sustainable way when there is the 'capital to be social' to bring them to life. Without this normative component of social capital, which explicitly has public welfare in mind, the effects of codes of conduct and the related monitoring systems will fizzle out at a certain point.

When managers have social capital as a resource and social capital as a capability, they can use and activate it for their own goals, such as their profit orientation. On the other hand, more activities to diffuse social standards can be observed in developed countries. This can be understood as the result of larger amounts of 'capital to be social' being embedded in developed societies. Because unions, networks, general trust in the legal system and the civil engagement of NGOs are generally common in developed countries, workers enjoy comparably good availability of different social capital components. This is different in developing countries, where fundamental labour rights are absent or violated. Here, workers do not have social capital as a resource, as a capability or as the 'capital to be social' to improve their working conditions. Additionally, social standards that are usually part of a code of conduct are less a part of the wider societal rules, 'scripts', values and norms of a society compared with developed countries. As a consequence, they are not considered or 'discovered' as something worthy. Spot-check monitoring, for example, cannot perform well without a minimum level of 'support' or 'understanding' on the part of the workers affected. There is no fertile ground in the form of social capital on which the social standards framed by a code of conduct can grow and diffuse in society. Bringing the above considerations together, it seems as if the diffusion of social standards not only requires 'top-down' codes of conduct and monitoring systems, but also 'bottom-up' social capital — and thus a combination of all three differentiated qualities. 
Theoretically, this sounds plausible. On the other hand, the question remains over how this can be achieved in practice. What practical relevance do the above considerations have-for the formulation of development policies on the one hand and for practitioners of development policies on the other? How does it affect not only NGOs and trade unions but also MNCs and their suppliers?

\section{Practical relevance}

In order to diffuse social standards throughout the supply chain and into developing countries, the monitoring of codes of conduct needs to be supplemented by social capital. Here the question arises of how social capital can be spread successfully and what policy implications this has.

As the above considerations have shown, social capital can be effective when it is composed of social capital as a resource, of social capital as a capability and of 'capital to be social'. Development policy should aim at furthering all three qualities of social capital. There is a variety of possible ways to do this. However, this requires a thorough analysis of the specific constellations in the country, the industry and the corporation concerned. Unfortunately, there is no optimum solution that can be applied to all thinkable situations. However, let me describe one possible example of how to strengthen social capital: the formation of multi-stakeholder round-tables.

Ideally, multi-stakeholder round-tables (MRTs) fulfil three functions: they are a resource for stakeholders, they make their participants capable, and they enable the development of 'capital to be social'. What forms can this take? When organised as a platform of communication for diverse and probably antagonistic stakeholders, MRTs are a resource for explanation and exchange. They offer the chance to make different opinions visible. Second, they make stakeholders potentially capable of convincing other stakeholders by building alliances with others. As such, they function as a form of social capital as a resource and of social capital as a capability that may be utilised for any goal depending on the prevailing power structures. The difficult part is now to add a normative component that unites all participants under a common banner, with the aim of promoting public welfare as defined by human rights and core labour standards. How can this be achieved in a situation where power structures are rather unequal?

A public-private partnership ( $\mathrm{PPP}$ ) project organised by the German retail sector is attempting to solve this problem. Jointly organised by the Foreign Trade Association of the German Retail Trade (Außenhandelsvereinigung des Deutschen Einzelhandels $[\mathrm{AVE}])$ on the private side and the German development agency, Deutsche Gesellschaft für Technische Zusammenarbeit (GTZ), on the public side, several retail MNCs originating from Germany have committed themselves to establishing a sector-wide code of conduct, laying down social standards throughout their supply chain. ${ }^{6}$ Additionally, MRTs have been established in II of the developing countries affected, inviting suppliers, trade unions and representatives from governments and NGOs to discuss any difficulties arising during the implementation of social standards in the supplier companies. ${ }^{7}$ All relevant meetings are organised and mediated by the German GTZ. As the economic

6 The PPP project is called 'AVE Sector Model Social Responsibility'. It was initiated by AVE in 2002. On the public side, the project is also overseen by the German Federal Ministry for Economic Cooperation and Development. The code of conduct to be established has been developed in accordance with the so-called 'social management system' of the standard Social Accountability 8000 (SA 8000) (AVE undated; GTZ undated). This standard has been formulated by the organisation Social Accountability International (SAI), and provides monitoring by an independent auditing corporation (Wick 2003: 36ff.; Reichert 2004: 20ff.; SAI undated).

7 Please see Round Table Codes of Conduct, www.coc-runder-tisch.de. 
pressure imposed by the MNCs coalesces here with the 'capital to be social' originating from the developed countries, all participants are encouraged to stay and (often for the first time) exchange their views. Theoretically, this specific situation could be the starting point for a power-free dialogue, while the 'capital to be social' that has built up over many generations in developed countries may provide the necessary spillover into developing countries. Ideally, the understanding for other stakeholders will grow within the MRTs, and shared norms and values will slowly emerge. At the end of the day, this may result in growing 'capital to be social' and accepted social standards.

However, in practice there are many difficulties involved. As organiser and mediator, the GTZ does not have sufficient knowledge of the 'landscape' of potential stakeholders and participants that exists in some countries. Especially on the side of the workers, it is difficult to find the right representatives. In countries where not even trade unions exist, it is virtually impossible to organise a power-free dialogue. Instead, the MRT may unconsciously reproduce the unequal social structures and hinder, rather than further, the diffusion of social standards. As a result, the likelihood of supporting clientelism may be greater than that of fighting it. Second, even when the organisers succeed in uniting all-important stakeholders at one table, this is no guarantee that an open exchange of views will take place: managers of supplier companies are sometimes not used to communicating with representatives from the workers' side; and knowledge about fundamental workers' rights as spelled out by the ILO does not exist and/or workers are afraid to speak frankly. Consequently, communication is difficult and time-consuming. As MRT meetings take place only every few months, progress is slow. In the meantime, established circles reflecting the power inequalities may become active in an attempt to remedy the slow progress that has been made. Altogether, the organisation of MRTs is a demanding task that costs time, money and much effort that might prove in vain when things go wrong. On the other hand, MRTs at least offer the chance to bring adverse groups together, to exchange their views and to develop a shared understanding. In this way, they function as catalysts and translators. They offer the chance for social capital to grow and develop in all its components. But it is still early days. The PPP project remains in its infancy, and it will be tempting to observe future developments.

\section{References}

Ascoly, N., and I. Zeldenrust (2003) Monitoring and Verification Terminology Guide for the Garment and Sportswear Industries (Centre for Research on Multinational Corporations; Amsterdam: Somo).

AVE (undated) 'Corporate Social Responsibility: Ensuring Social Standards. The Joint Initiative of the AVE', www.ave-koeln.de/csr/ave_sektorenmodell.htm, I8 September 2005.

Baron, S., J. Field and T. Schuller (eds.) (2000) Social Capital: Critical Perspectives (Oxford, UK: Oxford University Press).

Bourdieu, P. (I983) 'Ökonomisches Kapital, kulturelles Kapital, soziales Kapital', in R. Kreckel (ed.), Zur Theorie sozialer Ungleichheiten (Sonderband 2 der Sozialen Welt; Göttingen, Germany: Schwartz): I83-98.

Coleman, J.S. (I988) 'Social Capital in the Creation of Human Capital', American Journal of Sociology 94 (Supplement): S95-I20.

— (I990) Foundations of Social Theory (Cambridge, MA: The Belknap Press of Harvard University Press).

Dasgupta, P., and I. Serageldin (eds.) (2000) Social Capital: A Multifaceted Perspective (Washington, DC: World Bank).

Dolfsma, W., and C. Dannreuther (2003) 'Subjects and Boundaries: Contesting Social Capital-Based Policies', Journal of Economic Issues 37: 405-I3.

Field, J. (2003) Social Capital (London: Routledge). 
Fuchs, P. (2000) 'Codes of Conduct: Neue Handlungsoption zur Re-Regulierung transnationaler Konzerne “von unten”?’, in C. Dörrenbächer and D. Plehwe (eds.), Grenzenlose Kontrolle? Organisatorischer Wandel und politische Macht multinationaler Unternehmen (Berlin: edition sigma 2000): 289-307.

Fukuyama, F. (1995) Trust: The Social Virtues and Creation of Prosperity (London: Hamish Hamilton).

- (2000) Social Capital and Civil Society (International Monetary Fund Working Paper, WP/oo/74; Washington, DC: IMF): I-I8.

Gambetta, D. (ed.) (I988) Trust: Making and Breaking Cooperative Relations (Oxford, UK: Basil Blackwell). GTZ (Gesellschaft für Technische Zusammenarbeit) (undated) “ “Test” Gives GTZ-AVE Partnership Good Marks', www.gtz.de/en/leistungsangebote/4300.htm, I8 September 2005.

IG Metall Vorstand, Friedrich Ebert Stiftung, and DGB-Bildungswerk (eds.) (200I) Weltweit gegen Sozialdumping: Für Verhaltenskodizes (Frankfurt am Main, Germany: IG Metall).

ILO (International Labour Organisation) (undated) 'Standards and Fundamental Principles and Rights at Work', www.ilo.org/public/english/standards/index.htm, I6 January 2006.

_ (I998) 'Overview of Global Developments and Office Activities Concerning Codes of Conduct, Social Labelling and Other Private Sector Initiatives Addressing Labour Issues', www.ilo.org/ public/english/standards/relm/gb/docs/gb273/sdl-I.htm, I6 January 2006.

Lin, N. (200I) Social Capital: A Theory of Social Structure and Action (Cambridge, UK: Cambridge University Press).

— Gruyter).

Locke, R.M. (2003) 'The Promise and Perils of Globalization: The Case of Nike', in T.A. Kochan and R.L. Schmalensee (eds.), Management: Inventing and Delivering Its Future (Cambridge, MA: The MIT Press): 39-70.

Murray, J. (I998) Corporate Codes of Conduct and Labour Standards (ACTRAV Working Paper; Geneva: International Labour Organisation).

Ostrom, E., and T.K. Ahn (eds.) (2003) Foundations of Social Capital (Cheltenham, UK: Edward Elgar).

Putnam, R.D. (I993) Making Democracy Work: Civic Traditions in Modern Italy (Princeton, NJ: Princeton University Press).

_ _ (I995) 'Bowling Alone: America's Declining Social Capital', Journal of Democracy 6: 65-78.

- (2000) Bowling Alone: The Collapse and Revival of American Community (New York: Simon \& Schuster).

Reichert, T. (2004) Social Standards in the Global Economy (Eschborn, Germany: Deutsche Gesellschaft für Technische Zusammenarbeit [GTZ]).

Röben, B. (I999) 'Multis außer Kontrolle? Regulierungsansätze im Überblick', epd: Dritte Welt-Information 5/6 (April I999): I-I2.

SAI (Social Accountability International) (undated) 'Overview SA 8000', www.sa-intl.org/index.cfm? fuseaction=Page.viewPage\&pageId=473, I6 January 2006.

Solow, R.M. (2000) 'Notes on Social Capital and Economic Performance', in P. Dasgupta and I. Serageldin (eds.), Social Capital: A Multifaceted Perspective (Washington, DC: World Bank): 6-Io.

Urminsky, M. (200I) Self-regulation in the Workplace: Codes of Conduct, Social Labelling and Socially Responsible Investment (Working Paper No.I; Geneva: International Labour Office).

Wick, I. (2003) Workers' Tool or PR Ploy? A Guide to Codes of International Labour Practice (Bonn/Siegburg: Friedrich-Ebert-Stiftung and SÜDWIND Institut für Ökonomie und Ökumene, 3rd edn).

Windfuhr, M. (2004) Social Standards in Technical Cooperation (Eschborn, Germany: Deutsche Gesellschaft für Technische Zusammenarbeit [GTZ]).

Woolcock, M. (I998) 'Social Capital and Economic Development: Toward a Theoretical Synthesis and Policy Framework', Theory and Society 27.I: I5I-208.

_- (200I) 'The Place of Social Capital in Understanding Social and Economic Outcomes', Isuma: Canadian Journal of Policy Research 2.I: II-I7.

World Bank (I999) 'What is Social Capital?', wwwI.worldbank.org/prem/poverty/scapital/whatsc.htm, I6 January 2006. 
Copyright of Journal of Corporate Citizenship is the property of Greenleaf Publishing and its content may not be copied or emailed to multiple sites or posted to a listserv without the copyright holder's express written permission. However, users may print, download, or email articles for individual use. 